\title{
The Role of Psychology in Special Needs Education
}

\author{
Fattah Hanurawan \\ Universitas Negeri Malang, Indonesia \\ E-mail: fhanurawan@yahoo.com
}

\begin{abstract}
Special needs children are children who have disability, health or mental health or mental health conditions requiring early intervention requiring early intervention and supports. Psychology has important contributions to understanding, explanation, prediction, control, and solves problems of special needs children. The real contributions of the psychology are in a collaborative process with other stakeholders in a children's bio-psycho-social system. The system involves the children, family, community, educators and educational systems, and other professional. In this context, the contributions of psychologist are best given within a multi-disciplinary group. Psychologists apply psychology theories in understanding, explanation, prediction, control, and solve problems of special needs children. For applied psychologists, theories are the important tool for understanding, explaining, predicting, controlling, and solving problems of special needs children.
\end{abstract}

Keywords: psychology, special needs education.

In our global world there is a phenomenon of children with special needs. Children with special needs can be seen also in Indonesia. The special needs children are children with some cognitive, affective, and psychomotor limitations. The phenomena of special needs children include children with autism, children with mental retardation, children attention deficit hyperactivity disorder, and children with sensory, physical, and health impairments.

Because of their limitation (cognitive, affective, and psychomotor) they should be supported to adjusting themselves to their spiritual, social, and physical environment. In this context, the society and community where they live should support them so the children can live happily and wealthy. The support can be actualized through education for special needs children.

The educational support of the family, school, community, and society to the special needs children is relevant to Indonesia basic ideology, i.e. Pancasila that is about Indonesia as a wealthy nation. The Pancasila, specifically fifth foundation, states that every Indonesia citizen has a right to acquire a fair social justice in their live. The fulfillment of the rights can make them achieve their subjective well being or happiness and also achieve positive functioning (Baumgardner \& Crothers, 2010). The fulfillment of the special needs children rights through education can be seen also as a realization of Indonesia state tag, that is the unity in diversity (bhinneka tunggal ika), as a basic state symbol of Indonesia as a multicultural society. In this context, we can see that a special needs children group is one cultural group of the variety of groups, who live in Indonesia.

One way for family, school, community, and school to facilitate the special needs children is knowledge and practices about a psychology perspective towards special needs children. Psychology as a science of behaviour and mental phenomena can help through theories and practices to help special needs children adjust themselves to their environment. The effectiveness of the self-adjustment can help them in acquiring happiness and fulfilling their function in the family, school, community, society, and state.

\section{DISCUSSION}

\section{Special Needs Children}

Special needs children can be defined as children who have disability, health or mental health conditions requiring, early intervention requiring early interventions and supports. Disability is a limitation of functions of cognitive, affective, and psychomotor abilities. In area of education, special needs students can be defined as students who have cognitive, affective, and physical function is so different from the norm that additional treatments are needed to meet the students' needs (Slavin, 2006).

There are some types of special needs children. Some types of special needs children can be listed as follows: children with autism, children with mental retardation, children with attention deficit hyperactivity disorder, and children with sensory, physical, and 
health impairments.

Children with Autism. Autism is a pathological selfabsorption and preoccupation with the self to exclusion of the outside world (Colman, 2006). Autism is a developmental disability that seriously influences social interaction and communication (Slavin, 2006). Autism became a formal category of disability or special needs in year 1990. Children with autism is characterized by difficulties in developing social interaction, difficulties in developing social communication (verbal and non verbal) and interpersonal communication, and a tendency to involve in repetitive behaviours.

Symptoms of autism appear in infancy and early childhood. It can delay in many basic fields of development, mainly in social skills or human relations such as learning to communicate, play, and interact with others. Although some social difficulties, children with autism might have normal or outstanding competencies in certain fields (Slavin, 2006). Although autism is generally a life-long condition, children with autism can acquire benefit from therapies or interventions that can reduce symptoms and improve social skills and abilities. It can help them live in their social environment. Educators and psychologists can help them with the interventions and therapies as soon as possible.

Children with mental retardation. Children with mental retardation are children who have substantial limitations in present functioning. The substantial limitations are in adaptive skill areas as follows: communication, self-care, social skills, communication, community use, home living, functional academic, leisure and work, etc. Symptoms of mental retardation can be recognized before age 18 years.

There is a classification of children with mental retardation according to their IQ scores. The classification can be listed as : (1) Children with mild retardation (IQs 55 to 70), they are regarded as "educable"; (2) Children with moderate retardation (IQs about 55), they are regarded as "trainable"; (3) Children with "custodial" retardation (IQs below 50), they are out-of-schools- services (Slavin, 2006).

In general educator should help children who have mental retardation to acquire adaptive behaviour skills (Slavin, 2006).

Children with attention deficit hyperactivity disorder. Children with attention deficit hyperactivity disorder are children who have difficulties in maintaining attention because of a minimum ability to concentrate. The children attention with deficit hyperactivity disorder have characteristic: (a) attention deficits; (b) impulsive behaviour; (c) hyperactivity behaviour.

In educational setting, students with attention deficit hyperactivity disorder might have significant academic, behaviour, and social problems as results of their inability to concentrate or to pay attention. The mental disorder is characterized by persistent inattention and impulsivity with some of symptoms emerged before age 7 years, causing problems at home and school. The mental disorder of childhood affecting between two or ten per cent of school-age children in the world (Slavin, 2006).

Children with sensory, physical, and health impairments include children with sensory impairments, children with physical impairments, children with health impairments. Children with sensory impairments are children who have problems with the capacity to hear or see information through the body's sense. Examples of Children with sensory impairments are students with visual disabilities or students with deaf or hard of hearing.

Children with physical impairments are children who have physical disorders such as spinal cord injury, cerebral palsy, and muscular dystrophy. Children with health impairments are children who have health disorders, include acquired immune deficiency syndrome (AIDS), diabetes, child abuse, attempted suicide, etc (Slavin, 2006). In the area of education, educator should help them with some treatments or learning strategies so they can learn well in classrooms and schools.

\section{Psychology}

Hanurawan (2015) defines psychology as a scientific study of human behaviour and mental processes phenomena. The scientific study of psychology covers everything that people think (cognitive), feel (affective), and do (behaviour).

Purpose of psychology is to describe, explain, control, and solve problem towards mental and behaviour phenomena. The phenomena can be specified on phenomenon such as perception, human development, attitude, motivation, etc.

As a scientific study, psychology has some method for describing the objects of psychology (cognitive, affective, and behaviour). Generally, the methods familiar to psychology are positivistic, interpretive, and critical approaches (Hanurawan, 2010). The positivistic approach also can be called as quantitative research approach. The designs of the positivistic approach are laboratory experiment, field experiment, and field correlation. Instruments of the positivistic approach are structured observation, questionnaire, psychology assessment, and etc. Collected data is analyzed by statistical techniques such as t-test, correlation analysis, structured equation model, path analysis, and multiple regression analysis.

The interpretive approach also can be called as 
qualitative approach. Models or designs of the approach are case study, phenomenology, hermeneutic, and ethno methodology (Hanurawan, 2016a). The data collection methods in the qualitative research are unstructured observation or participant observation, documents, qualitative questionnaire, and written reflection journal. The collected data in qualitative research is analyzed using content analysis, descriptive analysis, thematic analysis, and phenomenological analysis. The validation process in qualitative research using some methods, such as triangulation or member check.

There are main fields in psychology. The fields are Social Psychology, Clinical Psychology, Educational Psychology, Developmental Psychology, Organizational and Industrial Psychology.

Social psychology. Social psychology is a field of psychology devoted to social behaviour. The objects learned in the social psychology include conformity, aggression behaviour, social attitude, close-relationship collective behaviour, social skills, etc.

Clinical psychology. Clinical psychology is a field of psychology concerned with the nature, diagnosis, classification, treatment, and prevention of "mental disorder and disabilities" (Colman, 2006).

Educational psychology. Educational psychology is a field of psychology concerned with the psychological dynamic in education setting (Colman, 2006). Topics of educational psychology include human development related to education, student diversity, learning, effective teaching, creativity in education, motivation in education, learners with exceptionalities, evaluation, etc.

Developmental psychology. Developmental psychology is the scientific study of psychology towards human change over the course of their life. Topics of the developmental psychology are controversies between nature and nurture, cognitive development, social and emotional development, physical development, moral development, childhood development, childhood development, adolescent development, adulthood development, and old age development, and parenting.

Organizational and industrial psychology. Organizational and industrial psychology is a field of psychology about human behaviour and mental process in the organizational and industrial settings. Topics of organizational and industrial psychology include remuneration and compensation, motivation in organization and industry, work stress, organizational culture, human factors engineering or ergonomic, work satisfaction, organizational citizenship behaviour, leadership, job analysis, personnel recruitment and selection, and training.

Beside the main fields of psychology, there are also many specific fields or subfields of psychology. The specific fields of psychology include ergonomic, environmental psychology, community psychology, forensic psychology, psychology of learning, counseling psychology, group psychology, psychology of motivation, etc.

\section{The Role of Psychology in Special Needs Children}

Psychology has important contributions to understanding, explanation, prediction, control, and solves problems of special needs children. The real contributions of the psychology are in a collaborative process with other stakeholders in a children's biopsycho-social system. The system involves the children, family, community, educators and educational systems, and other professional. In this context, the contributions of psychologist are best given within a multi-disciplinary group (Feehan et. al., 2003). The group collaboration will contribute an optimum impact to help special needs children developing their capabilities or life skills in their physical, social, and spiritual environment.

Psychologists apply psychology theories in understanding, explanation, prediction, control, and solve problems of special needs children. For applied psychologists, theories are the important tool for understanding, explaining, predicting, controlling, and solving problems of special needs children. The theories in psychology can be seen as the starting point for making prevention and intervention. A psychology theory is an organized set of principles that describes, explain, and predicts psychological phenomena (cognitive, affective, and psychomotor) (Schultz \& Estrada-Hollenbeck, 2008). The psychology theory can be used as a foundation for our efforts to change or to solve behaviour of children with special needs. Examples of psychology theories are social learning theory, behaviorist theory, cognitive theory, humanistic theory, psychoanalysis theory, and critical theory (Hanurawan, 2010).

The psychology theories that can be applied to children with special needs problems can be drawn and developed from fields of psychology. Consistent to existence of main fields of psychology, a study of special needs children from a psychology perspective can be viewed from five fields of psychology, i.e. social psychology perspective, clinical psychology perspective, developmental psychology, industrial and organizational psychology, and educational psychology.

Social psychology role. Through theories and practices of social psychology, the psychologists and educators can develop special needs children with interpersonal and social skills. The interpersonal and social skills include interpersonal and social perception, interpersonal and social communications, social attitudes, monitoring and controlling aggression behaviour and anger, citizenship behaviour skills for 
living in group, organization, and community, and resolving interpersonal and social conflict life skills. The social skills are very important to special needs children because through the skills they have abilities to socialize or to integrate them to social context, such as family, community, school, society, and state.

Clinical psychology role. Through theories and practices of clinical psychology, the psychologists and educators can develop a good mental health special needs children. Psychologists develop the mental health through intervention such as assessment, clinical consultation, positive behavioural support, therapy, facilitation of family support, and liaison with statutory and voluntary bodies (Feehan et. al., 2003). A good mental health is very important for children with special needs, therefore they must to develop strategies for coping with difficult situations and methods of solving the problems appropriately. The problems of mental health of children with special needs can be listed as follows: anxiety, depression, serious mental illness (Better, 2016). The other problems of mental health are loneliness, low self concept, and low self esteem. There are theories of therapies that can applied to the special needs children' mental health, e.g. cognitive behavioral therapy, dialectic behavioural therapy, psychodynamic therapy, and humanistic therapy. The therapy practices of clinical psychology in a positive psychology era should introduce and develop positive concept to children with special needs, such as subjective well being, hope, optimism, resiliency, virtue, wisdom, spirituality, etc (Baumgardner \& Crothers, 2010).

Developmental psychology role. Development theories of developmental psychology apply theory and practices of cognitive, affective, moral, physic, and social development in special needs children. The theories of developmental psychology include Vygotsky theory, Piaget theory, Kohlberg theory, and Freud theory. Developmental psychologists observe the developmental problems of children with special needs and then recommend the appropriate prevention and intervention to the problems.

Educational psychology role. Theories in educational psychology can be used for helping special needs children in areas of education, such as in schools. The main task of teachers is to teach the children with special needs effectively, there are some general concepts of effective teaching to special needs children, include: emphasize prevention, teach learning-to-learn skills, give frequent feedback, use a variety teaching strategies that engage students actively in lessons, use effective classroom management methods, and coordinate supplementary services with classroom instruction.

Beside in the area of effective teaching, educational psychologists also apply psychological theories in educational issues. The educational issues relevant to special needs children are educational motivation (internal or external), inclusion, learning assessment, school and classroom environment, student's diversity, and sex education for autism children (Rahmawati, 2012).

Educational psychology applied to special needs education means application of theory and practice of psychology of education to educating students with special needs in a way that addresses their individual differences and needs. In collaboration with special need educators, educational psychologists develop and design special instructional learning strategies, materials, and learning tools to meet educational needs of special needs children.

Industrial and organizational psychology role. Industrial and organizational psychology contributes to children with special needs in the context of cognitive, affective, and behaviour skills at work and career mapping. It can be conducted by industrial and organizational psychologists and educators by consultation and special training. Industrial and organizational psychology also contributes to children with special needs through sub-fields of industrial and organizational psychology, i.e. ergonomic or human factors engineering. The ergonomic is a sub-field of industrial and organizational psychology which can be defined as a study of designing equipment, devices, and process that fit the human physiology, psychology, and anthropometry characteristic. The purpose of ergonomics is to fulfill occupational health and safety and productivity. The ergonomic can be applied in educational settings (Hanurawan, 2016b).

Contributions of ergonomic to special needs children is through designing physical environments and tools that are suitable to special needs children characteristics. The characteristics include psychological, physiological, and anthropometric. Ergonomists design special products for children with special needs, such as a special learning chair for children with physical problems. A fit proper design for children with special needs is necessary to prevent repetitive strain injuries and other musculoskeletal disorder which can lead to long term disability.

\section{CONCLUSION AND SUGGESTION}

On the basis of description of the role of psychology in special needs education we can draw some conclusions. The conclusions can be listed as follows:

Special needs children are children who have disability, health or mental health or mental health conditions requiring early intervention requiring early intervention and supports. Types of special needs 
children are children with autism, children with mental retardation, children with attention deficit hyperactivity disorder, and children with sensory, physical, and health impairments.

Special needs children have rights to live happily and wealthy in Indonesia as a multicultural society based on the principle of the Pancasila and the bhinneka tunggal ika. The rights can be actualized through special needs education.

Psychology is a science of behaviour and mental processes. The psychology has important role in educating children with special needs through application of psychology theories and practices (social psychology, clinical psychology, and developmental psychology, and educational psychology, industrial and organizational psychology).

The suggestion can be listed as follows: The psychologists give their contribution to special needs children through a collaborative process with other stakeholders in a children's bio-psycho-social system. The system includes involves the children, family, community, educators and educational systems, and other professional. The contribution can have significant impact on special children autonomy.

The psychologists use the theories and practices from the main fields of psychology in educating special needs children comprehensively. The main fields are social psychology, educational psychology, clinical psychology, developmental psychology, and industrial and organizational psychology.

\section{REFERENCES}

Baumgardner, S. R. \& Crothers, M. K. (2010). Positive Psychology. Upper Saddle River New York: Pearson Prentice Hall.

Better, O. N. D. (2016). Children and Young People with Learning Disabilities. Understanding Their Mental Health. London: Bond c/o Youngminds.

Colman, A. M. (2006). A Dictionary of Psychology. New York: Oxford University Press.

Feehan, S., McCharty, Y., \& White, C. (2003). The role of psychologist with school age children with an intellectual disability. A brother of charity guidelines document for psychologist working in special schools in the southern services.

Hanurawan, F. (2010). Psikologi sosial suatu pengantar. Bandung: Rosdakarya.

Hanurawan, F. (2015). Ilmu Psikologi untuk Pemecahan Masalah Kemanusiaan. Professorship Oration. Universitas Negeri Malang.

Hanurawan, F. (2016a). Metode Penelitian Kualitatif: Untuk Ilmu Psikologi.
Hanurawan, F. (2016b). Perspektif Alternatif dalam Psikologi Pendidikan. Malang: Universitas Negeri Malang.

Rahmawati, F. 2012. Pendidikan Seks untuk Anak Autis. Jakarta: PT Elex Media Komputindo.

Slavin, R. E. (2006). Educational Psychology. Theory and Practices. Boston: Pearson Allyn and Bacon.

Schultz, P. W., \& Estrada-Hollenbeck, M. I. C. A. (2008). The use of theory in applied social psychology. Applied social psychology. Cambridge University Press, Cambridge, 28-49. 